\title{
Electrophoretic Determination of Lactococcus lactis Modified by Zinc Ions
}

\author{
B. Buszewski ${ }^{1,2}$ (1) A. Król ${ }^{1,2} \cdot$ P. Pomastowski ${ }^{2} \cdot$ V. Railean-Plugaru" ${ }^{1,2} \cdot$ Małgorzata Szultka-Młyńska $^{1,2}$
}

Received: 29 June 2018 / Revised: 3 October 2018 / Accepted: 15 November 2018 / Published online: 29 November 2018

(c) The Author(s) 2018

\begin{abstract}
The developed capillary electrophoresis (CE) method was applied to evaluate the aggregation activity of divalent metal ions (zinc) on bacterial cells. In our study, the influence of the Lactococcus lactis surface modification by zinc ions at different concentration (1,3 and $10 \mathrm{mM}$, respectively) was determined. Electrophoretic results in pseudo isotachophoretic mode indicated that using a $\mathrm{Zn}_{\mathrm{aq}}{ }^{2+}$ caused the uncontrolled aggregation of bacterial cells and, as a result, new signals of microbial agglomerates were observed in the electropherogram. Moreover, the observed process is strongly related with the concentration of the used $\mathrm{Zn}_{\mathrm{aq}}{ }^{2+}$ solution - the number of bacterial agglomerates increased with an increasing concentration of modifier. The phenomenon of L. lactis uncontrolled clumping was also evaluated by application of size distribution and spectrometric in infrared range measurements (FT-IR) measurements. The obtained data indicated that the main groups involved in the bacterial cells aggregation process are deprotonated carboxyl and amid groups derived from microbial surface proteins. As a consequence, the proposed mechanism of the L. lactis uncontrolled clumping process is presented. In addition, data from fluorescence microscopy pointed out damage cells analyzed direct after electroanalysis. Therefore, CE may be a potential method for evaluating the aggregation activity of different types of bivalent metal ions against microbial cells.
\end{abstract}

Keywords Capillary electrophoresis $\cdot$ Bacterial aggregation $\cdot$ Mechanism $\cdot$ Zinc ions $\cdot$ Lactococcus lactis

\section{Introduction}

Nowadays, the use of capillary electrophoresis (CE) for the analysis, identification, and characterization of different types of microorganisms has received much limited attention. This technique has been found to provide many advantages such as high separation efficiency, short analysis time or the possibility of direct analysis of biological samples [1-4]. There

Published in Chromatographia's 50th Anniversary

Commemorative Issue.

Electronic supplementary material The online version of this article (https://doi.org/10.1007/s10337-018-3665-3) contains supplementary material, which is available to authorized users.

B. Buszewski

bbusz@chem.umk.pl

1 Faculty of Chemistry, Nicolaus Copernicus University, 7 Gagarina Str., 87-100 Toruń, Poland

2 Centre for Modern Interdisciplinary Technologies, Nicolaus Copernicus University, 7 Gagarina Str., 87-100 Toruń, Poland is a few examples of the CE use for the determination of bacterial pathogens [5-7], yeast cells [8] or various types of human and plant viruses $[9,10]$. Although this analytical method provides many solutions in the field of the microorganisms identification, it is important to remember about its limitations and drawbacks such as uncontrolled aggregation (clumping) of bacterial cells and their adhesion to the capillary surface $[5,11]$. This can also be a source of capillary clogging, if aggregation occurs to a large extent. Moreover, factors such as $\mathrm{pH}$, osmolarity, or high electric fields, can also affect the analysis of bacterial cells by CE [12]. Microorganisms, according to the electrokinetic theory, are often consider as a biocolloids, mainly due to the complex structure of their cell wall and formed protonation equilibria at interface, and the understanding of the electrophoretic process is more complicated for such a system. The cell wall composition is characteristic for various types of bacterial species- they have different content of proteins, phospholipids, polysaccharides or another organic components [13]. The structure of the cell wall also determines the division of bacteria into two main types-Gram(+) and Gram(-). The major component is a peptidoglycan, a biopolymer consisting of $\mathrm{N}$-acetylmuramic 
acid and $\mathrm{N}$-acetylglucosamine with attached the peptide chain of three amino acids [14]. All compounds present in the bacterial cell wall structure strongly affects the surface charge of microorganisms. It can be explained by the presence of many functional groups undergoing the protonation process. Therefore, it is important to develop a method allowing to minimalize the uncontrolled aggregation and adhesion problem. Some research groups have proposed the addition of poly(ethylene oxide) (PEO) to the buffer solution [15-17] which functioned as a focusing agent. Kłodzińska et al. [17] have identified the E. coli and H. pylori in human urine by using PEO in the CE analysis. Another approach is capillary surface modification by the chemicals such as divinylbenzene (DVB) or trimethylchlorosilane acrylamide [18, 19]—Buszewski et al. [18] have used a chemical modification for the separation of the four bacterial strains. Moreover, Yu and Li [20] have emphasized the importance of the proper bacteria samples preparationthe vortex and sonication processes seem to be crucial in the decreasing of the microorganisms aggregation level. Recently, the new approach was suggested; it is based on the modification of the bacterial surface by specific divalent metal ions such as e.g. calcium [17, 21]. Application of this method may result in the controlled aggregation of microorganisms cells. Rogowska et al. [21] have investigated the impact of the cells surface modification by $\mathrm{Ca}^{2+}$ ions on the control clumping of S. cerevisiae and on the effectiveness of electrophoretic mobility. Although several surface modifications by calcium ions have been evaluated for the separation of microorganisms [17, 21], there is a lack of papers described bacteria surface modification via another types of divalent metal ions, e.g. zinc ions $\left(\mathrm{Zn}^{2+}\right)$. Therefore, understanding the influence of different ions on microorganisms surfaces and their potential use for further modifications, is pivotal for analytical chemistry.

Such a problem led our research group to the main task of the experiments presented in this paper - the aim of this study was to investigate the electrophoretic behavior of lactic acid strain of Gram(+) Lactococcus lactis during $\mathrm{CE}$ analysis and to examine the influence of $\mathrm{Zn}_{\mathrm{aq}}{ }^{2+}$ ions at different concentration on the bacterial cells aggregation. Furthermore, the size distribution, spectrometric in infrared range measurements and viability assay of L. lactis before and after $\mathrm{CE}$ analysis by using fluorescence microscopy was performed.

\section{Materials and Methods}

\section{Materials}

All solvents and materials were purchased from Avantor Gliwice (Poland). Ultra-pure water was obtained from Milli-Q RG system by Millipore (Millipore Intertech, Bedford, MA, USA). Lactoccocus lactis 56 used in this study, deposited in the Polish Collection of Microorganisms (PCM) under deposit no. B/00116 [22], were cultured in Tryptone Soya Agar (Soybean Casein Digest Medium, Oxoid, Basingstoke, United Kingdom).

\section{Sample Preparation for CE Analysis}

The required number of cells in $1 \mathrm{~mL}$ of the suspension was achieved by the serial dilution and the final number of L. lactis cells was $9 \times 10^{8} \mathrm{CFU} / \mathrm{mL}$. Afterwards the bacteria were separated from the medium by centrifugation $\left(20{ }^{\circ} \mathrm{C}, 9000 \mathrm{rpm}, 15 \mathrm{~min}\right)$. The bacterial pellet were then suspended in the solution of zinc nitrate at 1,3 or $10 \mathrm{mM}$ concentration and incubated for $1 \mathrm{~h}$ at the room temperature. After the incubation, the suspension was centrifuged $\left(20{ }^{\circ} \mathrm{C}, 9000 \mathrm{rpm}, 15 \mathrm{~min}\right)$. The obtained precipitate was washed twice with distilled water to remove unbound $\mathrm{Zn}^{2+}$ ions and after that transferred to the outlet TB buffer (Tris and boric acid; $\mathrm{pH}=8.0$ ). As a control, unmodified L. lactis cells were used.

\section{Capillary Electrophoresis Analysis}

CE analysis were performed using PA 800 plus Beckman Coutner system, Brea, CA, USA equipped with a DAD with the use of fused silica capillary (id $=75 \mu \mathrm{m} ; L_{\mathrm{tot}}=33.5 \mathrm{~cm}$; $L_{\text {eff }}=25 \mathrm{~cm}$; Composite Metal Services, Shipley, United Kingdom). Before the use, a new capillary was rinsed with $1 \mathrm{M} \mathrm{NaOH}$, deionized water, and TB (outlet buffer) for $10 \mathrm{~min}$. The bacterial samples were injected into the capillary with a pressure mode (10 psi, $8 \mathrm{~s})$ and the analysis were performed at a constant voltage $(20 \mathrm{kV})$ and the temperature at $23{ }^{\circ} \mathrm{C}$. As the inlet buffer, TBH (Tris, boric acid and hydrochloric acid; $\mathrm{pH}=7.3$ ) were choose. The samples were detected at $\lambda=214 \mathrm{~nm}$. Between runs, the capillaries were washed with $0.1 \mathrm{M} \mathrm{NaOH}$, deionized water and running buffer for 2 min each.

The electrophoretic mobility of L. lactis during the CE assay was calculated from the equation:

$\mu_{\mathrm{e}}=\frac{L_{\mathrm{tot}} \mathrm{L}_{\mathrm{eff}}}{V}\left(\frac{1}{t_{\mathrm{m}}}-\frac{1}{t_{\mathrm{EOF}}}\right)$,

where $\mu_{\mathrm{e}}$ is an electrophoretic mobility, $L_{\mathrm{tot}}$ is the total length of the capillary, $L_{\text {eff }}$ is the length to the detector, $t_{\mathrm{m}}$ is the migration time and $V$ is the applied potential.

\section{Fourier Transform Infrared Spectroscopy Analysis}

The determination of active functional groups present on the L. lactis surface before and after $\mathrm{Zn}_{\mathrm{aq}}{ }^{2+}$ modification were performed using FT-IR method (Direct Detect spectrophotometer, Merck Millipore, Germany). $2 \mu \mathrm{L}$ of sample was 
pressed into a card and dried. All IR spectra were recorded at room temperature in the range of $v=1350-1850 \mathrm{~cm}^{-1}$.

\section{L. lactis Cells Size Determination}

The size of non-modified and modified Lactococcus lactis cells was determined using the Mastersizer 3000 (Malvern Panalytical, Malvern, United Kingdom).

\section{Fluorescence Microscopy Analysis}

Determination of Lactococcus lactis cells viability before and after the CE analysis was performed by using fluorescence microscopy approach according to the [22]. During the $\mathrm{CE}$ analysis, fractions of bacterial cells not and modified with zinc ions were collected. Obtained bacterial samples were then stained with acridine orange $(0.12 \mu \mathrm{g} / \mathrm{mL})$ and ethidium bromide $(0.4 \mu \mathrm{g} / \mathrm{mL})$ and analyzed using a Zeiss Axio Observer.D1 (Zeiss, Oberkochen, Germany) fluorescence microscope with the set of filters $(43 \mathrm{He}$ and 38). Recorded images were analyzed with Axio Vision 4.8. software.

\section{Results and Discussion}

In this study, Gram(+) Lactococcus lactis modified with the different concentration of zinc ions $(1,3$ and $10 \mathrm{mM})$ were examined in an applied voltage of $20 \mathrm{kV}$. Bacterial strain without any surface modification was tested as a control sample (Fig. 1a). The electromigration time of the probiotic strain modified by the zinc nitrate solution at concentration of 1,3 and $10 \mathrm{mM}$ was $2.026(\mathrm{RSD}=0.784 \%)$, $2.064(\mathrm{RSD}=1.287 \%)$ and $2.083(\mathrm{RSD}=0.512 \%) \mathrm{min}$ respectively. Application of electrophoretic buffers (TB and TBH; isotachophoretic mode of CE) and without the surface modification by $\mathrm{Zn}_{\mathrm{aq}}{ }^{2+}$ allowed focusing the zone at the electromigration time of $1.670 \mathrm{~min}(\mathrm{RSD}=1.794 \%)$. It is in a good correlation with the results obtained by Pomastowski et al. [23], who have observed the peak of Lactococcus lactis ATCC 11454 at migration time of about $2 \mathrm{~min}$. Such a short electromigration time can be explained by the higher zeta potential of Gram(+) strain in comparison with Gram(-) bacterial cells in used buffer system [23]. All electrophoretic analysis were in the range of $0.1-3 \%$ RSD (Table S1). Moreover, the value of $L$. lactis electrophoretic mobility ( $\mu$, $\mathrm{cm}^{2} / \mathrm{Vs}$ ) non- and modified with zinc ions were decreasing with the increasing CE duration time (Table S1).

Adhesion to the capillary surface and uncontrolled clumping of bacterial cells is a significant drawback of capillary electrophoresis and many researcher groups have tried to develop an efficient method to eliminate this problem. One of the popular approach is bacterial surface modification by specific divalent metal ions such as e.g. calcium, which is believed to be one of the most important factors enabling aggregation of bacterial cells [24, 25]. Rogowska et al. [21] have examined the impact of the cells surface modification by $\mathrm{Ca}^{2+}$ ions on the control of the yeast cells analysis by capillary electrophoresis. The results pointed out the crucial impact of the microorganism surface modification on its electrophoretic mobility. During the $\mathrm{CE}$ analysis of Saccharomyces cerevisiae modified by $5 \mathrm{mM} \mathrm{Ca}^{2+}$ and with the increasing value of medium $\mathrm{pH}$, they observed the increase in the electromigration time of modified yeast cells and decrease in the electrophoretic mobility. In addition, the surface modification resulted in the sharpening of the peaks and the reduction in the number of aggregates of $S$. cerevisiae. It was correlated with the function of calcium ions in the controlled clumping of yeast cells by the binding surfacecarboxyl groups or lectin-like mechanisms of flocculation in which $\mathrm{Ca}^{2+}$ enables the lectins to acquire a suitable active conformation and thus interact with carbohydrate residues of $\alpha$-mannans present on the cell surface [24]. Furthermore, the study of Rogowska et al. [21] have shown that $\mathrm{pH}$ value of culture medium is a significant factor since its changes the ionization of the functional residues present on the cell surface, mainly the carboxyl group, thus modifying the availability of $\mathrm{Ca}^{2+}$ and allow the collecting of $S$. cerevisiae zone in CE. The same observation have described Pomastowski et al. [23] who have noted that the change in the electrophoretic mobility of different types of bacteria cells and the reduction of repulsive forces by $\mathrm{Ca}^{2+}$ surface modification resulted in signal amplification. However, described results indicated the promising use of calcium ions in the controlled clumping of microorganisms [21, 23], the role of other physiologically important bivalent metals has been largely neglected. Accordingly, the main aim of our study was to investigate the impact of L. lactis surface modification with $\mathrm{Zn}_{\mathrm{aq}}{ }^{2+}$ at their electrophoretic mobility and aggregation process. The most widely used thermodynamic model for the description of the aggregation phenomenon is DLVO (Derjaguin, Landau, Verwey, Overbeek) theory. Bacterial adhesions mediated by interplay between Lifshitz-van der Waals forces and electrostatic interactions originating from the overlap of electrical double layers and the solid surface. This theory has been extended to acid-base interactions [24]. It is in a good correlation with the chemical properties of the zinc element and may allow to described the possible mechanism of the Lactococcus lactis uncontrolled clumping mechanism.

Zinc is one of the most essential microelements and is crucial for the proper function of a large number of macromolecules and enzymes as far it participates in bone mineralization, healing wounds and is responsible for the proper functioning of the immune system or insulin secretion [25]. In 1956, G. Schwarzenbach and Ahrland Chatt and Davis 


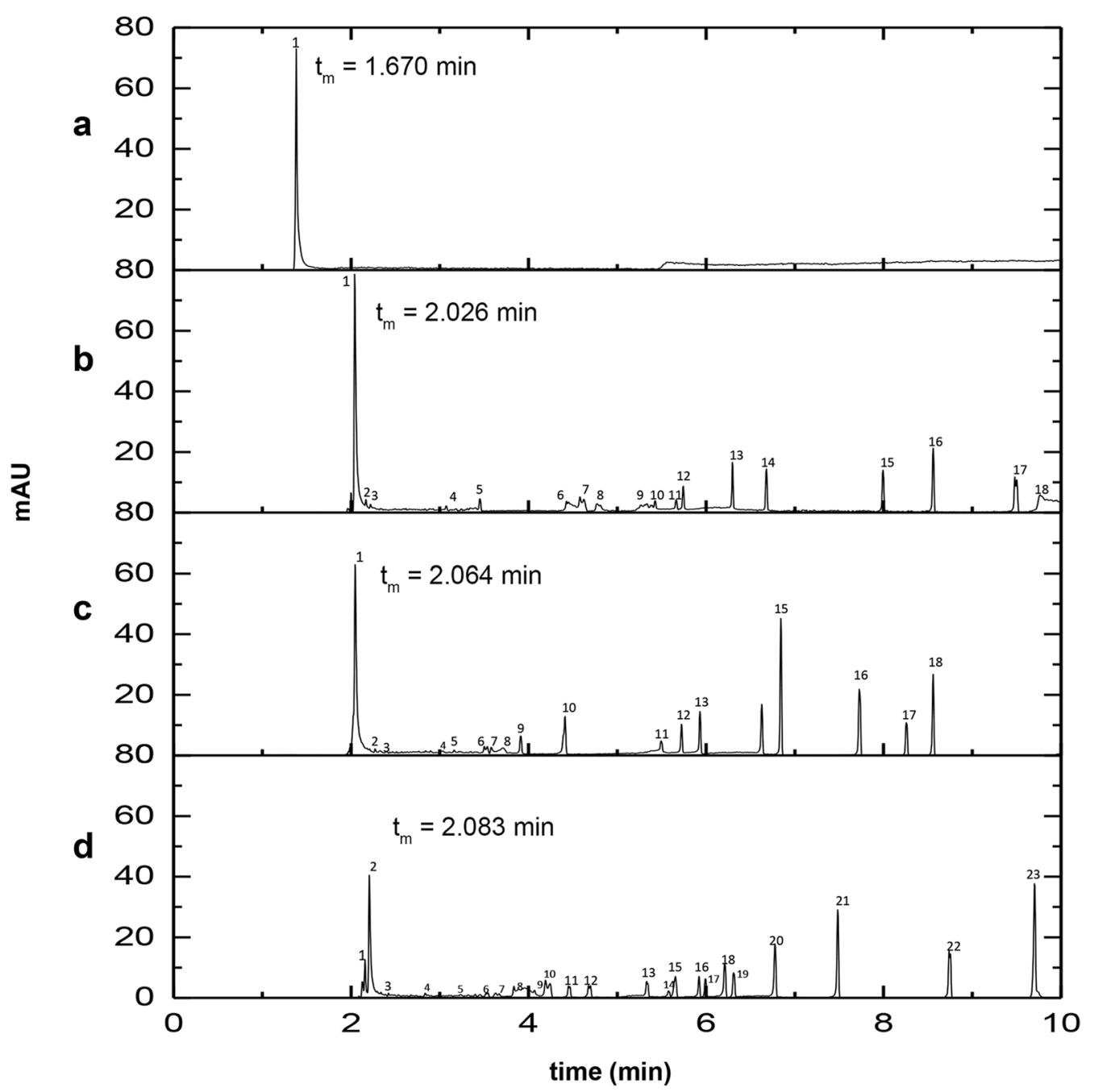

Fig. 1 Electropherogram of non-modified L. lactis (a); modified $L$. lactis by $1 \mathrm{mM}(\mathbf{b}), 3 \mathrm{mM}(\mathbf{c})$ and $10 \mathrm{mM}(\mathbf{d}) \mathrm{Zn}\left(\mathrm{NO}_{3}\right)_{2}$. Conditions: inlet buffer: TBH $(\mathrm{pH}=7.3)$, outlet buffer: $\mathrm{TB}(\mathrm{pH}=8)$, suspensive

$[26,27]$ classified the metal ions into two classes called $a$ and $b$ types. Those two research groups have explained that the class $a$ t of metals prefer to bind with class $a$ of donors and accordingly class $b$ of metals prefer to interact with class $b$ of donors. It was also proved that such an interaction shall lead to the formation of a more stable compound. Metal cations $\left(\mathrm{Me}^{2+}\right)$ with the completely filled d-electron shells such as e.g. zinc ions $\left(\mathrm{Zn}^{2+}\right)$, belongs to the second group in which the interactions with the ligand are predominantly covalent. Zinc has also an exceptional coordination chemistry - in the acidic aqueous solution zinc forms the colourless stable aqua complexes, $\left[\mathrm{Zn}\left(\mathrm{H}_{2} \mathrm{O}\right)_{6}\right]^{2+}$ which are acids according to the Brønsted-Lowry theory [28]. Furthermore, it may exchange their water molecules when binding to other ligands [29]. The interaction between zinc and ligands (water or organic anions) is highly connected to its nature but is not widely described in the literature. The polarization of water buffer: TB $(\mathrm{pH}=8) ; I=100 \mu \mathrm{A}, U=20 \mathrm{kV}, t=23{ }^{\circ} \mathrm{C}, \lambda=214 \mathrm{~nm}$, $L=33.5 \mathrm{~cm}, L_{\mathrm{eff}}=25 \mathrm{~cm}, \varphi=100 \mu \mathrm{m}$, injection: $10 \mathrm{psi}, t=8 \mathrm{~s}$

molecules by the central zinc ion causes the dissociation of a proton and as a result, an aqua-hydroxo complex is formed. Further, the deprotonation process of zinc aqua complexes leads to the formation of species with different charges - they are crucial for interaction with proteins and other groups of ligands [29-30].

Despite its pivotal properties, zinc ions may play an important role in the adhesion and biofilm formation by microorganisms. Biofilms are the most common type of bacterial growth in nature and consist of the microbial cells adhesion within the extracellular polymeric substances (EPS), a composition of extracellular polysaccharides and proteins [31]. However, in contrast to calcium chemistry, the zinc ions are d-electrons elements, possess Levis acid properties, caused the spontaneous interaction with active Levis base such as amino groups components of bacterial cell walls [32]. Moreover, the ability to form biofilms and 
aggregates is characteristic of some lactic acid bacteria (LABs) such as e.g. Lactobacillus rhamnosus or Lactobacillus plantarum [33]. The formation of the specific microbial biofilm is affected by many factors, including the properties of the bacterial surface, medium $\mathrm{pH}$ and composition or temperature. Another crucial factor can be addition of the metal ions to the nutrient or surface modification by $\mathrm{Me}^{2+}$. Work of the Formosa-Dague [34] have shown that zinc ions strongly increases the bacterial cell wall rigidity and activates the adhesive function of Staphylococcus aureus surface protein (SasG). They have tested the influence of the $1 \mathrm{mM}$ zinc chloride $\left(\mathrm{ZnCl}_{2}\right)$ on the biophysical properties of the $S$. aureus surface. After addition of the zinc ions, cell aggregates at 5-10 $\mu \mathrm{m}$ in size were observed in bacteria with the SasG protein expressing. Those results were confirmed by data collected from the AFM study which pointed out that addition of $\mathrm{Zn}^{2+}$ greatly changed the adhesive properties of microbial surface and caused formation of bacterial agglomerates. Brown et al. [35] also investigated the influence of the zinc on the biofilms formation and their results shown that with the $\mathrm{Zn}^{2+}$ concentrations increase, the aggregation of bacteria rise too. The described effect was found to be zinc-specific, because another types of ions (copper and manganese) did not affect biofilm formation. Outcomes of our study show that after the L. lactis surface modification by $\mathrm{Zn}_{\mathrm{aq}}{ }^{2+}$ ions, the formation of bacterial aggregates with different size and surface charge occurred; it was observed by an increasing number of signals in the electropherograms (Fig. 1b-d). The number of bacterial agglomerates rises with an increasing concentration of modifier. In the case of 1 and $3 \mathrm{mM}$ modification, the number of $\mathrm{CE}$ zones occurred at 18 , whereas using of $10 \mathrm{mM}$ zinc nitrate resulted in the observation of 23 signals. What is more, the study of the size of modified Lactoccocus lactis cells indicates that the zinc ions have a significant impact on the size distribution of the examined cells in comparison with the control sample (Fig. 3). It corresponds to the predicted size of unmodified L. lactis-from 0.5 to $1.5 \mu \mathrm{m}$ [36]. The observed differences in the intensity, number and time of some signals, can be a consequence of the various sorption and interaction of zinc at different concentration level with active functional group of e.g. bacterial proteins. Our previous work [37] have shown that addition of $3 \mathrm{mM}$ zinc nitrate to the Lactobacillus paracasei LB3 cell suspension have resulted in the intracellular formation of zinc oxide nanocomposites which could also form aggregates and be observed as a multiplied signals on the CE electropherogram. According to their data from FT-IR analysis, the main groups involved in the $\mathrm{ZnO}$ biosynthesis are carboxyl and amid groups derived from bacterial proteins. It is strongly related with results obtained in our study-Fig. 2 shows the FT-IR spectra of L. lactis unmodified and modified by $\mathrm{Zn}_{\mathrm{aq}}{ }^{2+}$ ions. It indicated that the main groups involved in the bacterial cells aggregation process are deprotonated carboxyl groups (spectral bands at $v=1530-1560 \mathrm{~cm}^{-1}$ ) (2) which can derive from aminoacids of bacterial proteins as well as peptidoglycan of their cell wall $[38,39]$. The spectra band at $v=1610-1670 \mathrm{~cm}^{-1}$ (3) corresponds with amide groups of bacterial proteins. Another characteristic band appears at $v=1440 \mathrm{~cm}^{-1}$ (1) may derives from the stretching vibration of $\mathrm{C}-\mathrm{N}$ and $\mathrm{N}-\mathrm{H}$ bond from surface microbial proteins. Furthermore, as a result of the modification, the increase of the signal at $v=1720 \mathrm{~cm}^{-1}$ (4) intensity can be observed. It is related with the stretching vibration of carbonyl groups $(\mathrm{C}=\mathrm{O})$. The obtained data prove that the examined bacterial strain exhibits the ability of the sorption of divalent metal cations such as zinc ions. Additionally, it can be observed that the most significant changes occur in the spectrum of the Lactococcus lactis modified by $10 \mathrm{mM}$ zinc nitrate. It is in a good correlation with the knowledge about interactions between zinc and functional groups presented on the biocolloids surface such as bacterial cells. Pomastowski et al. [39] have also performed the FT-IR analysis and proved that carboxyl groups of amino acids residues (e.g. asparagine and glutamine) are mainly involved in the described phenomena. The proposed mechanism of the uncontrolled clumping of Lactococcus lactis caused by the $\mathrm{Zn}_{\mathrm{aq}}{ }^{2+}$ ions is shown in the Fig. 4 .

Capillary electrophoresis has already been useful in the identification of pathogens [5-7], yeast cells [8] or various types of viruses $[9,10]$. A CE approach has also been applied for the direct detect of the Hela cells apoptosis [40].

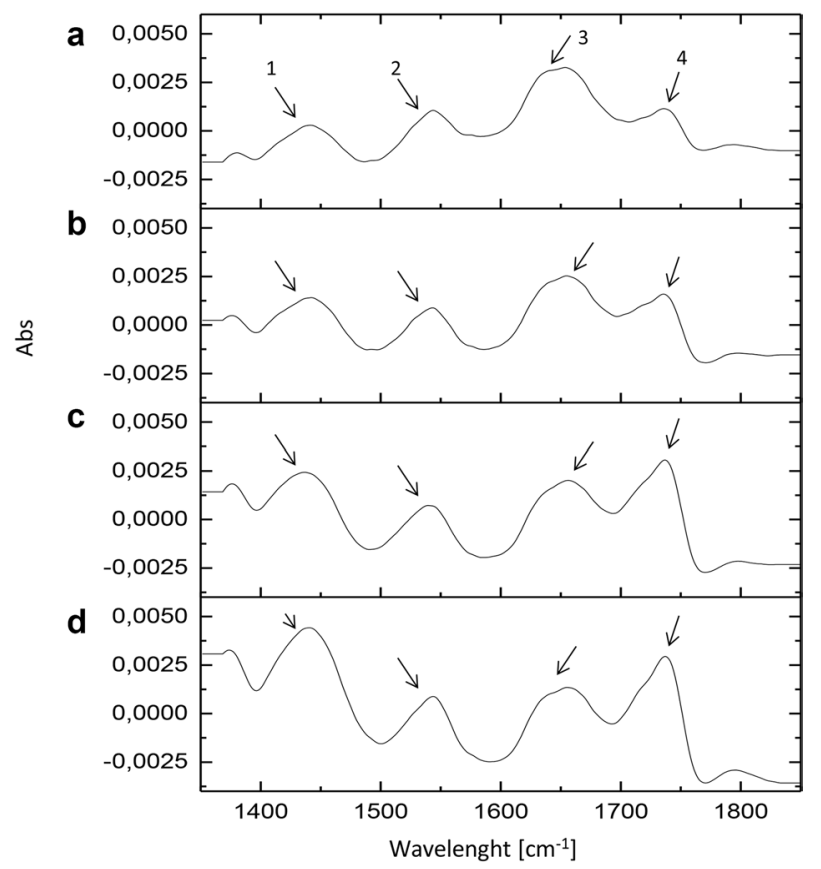

Fig. 2 FT-IR spectra for non-modified $L$. lactis (a) and modified $L$. lactis by $1 \mathrm{mM}(\mathbf{b}), 3 \mathrm{mM}(\mathbf{c})$ and $10 \mathrm{mM}(\mathbf{d}) \mathrm{Zn}\left(\mathrm{NO}_{3}\right)_{2}, v\left(\mathrm{~cm}^{-1}\right): 1$ : 1420-1480, 2: 1530-1560, 3: 1610-1670, 4: 1710-1740 


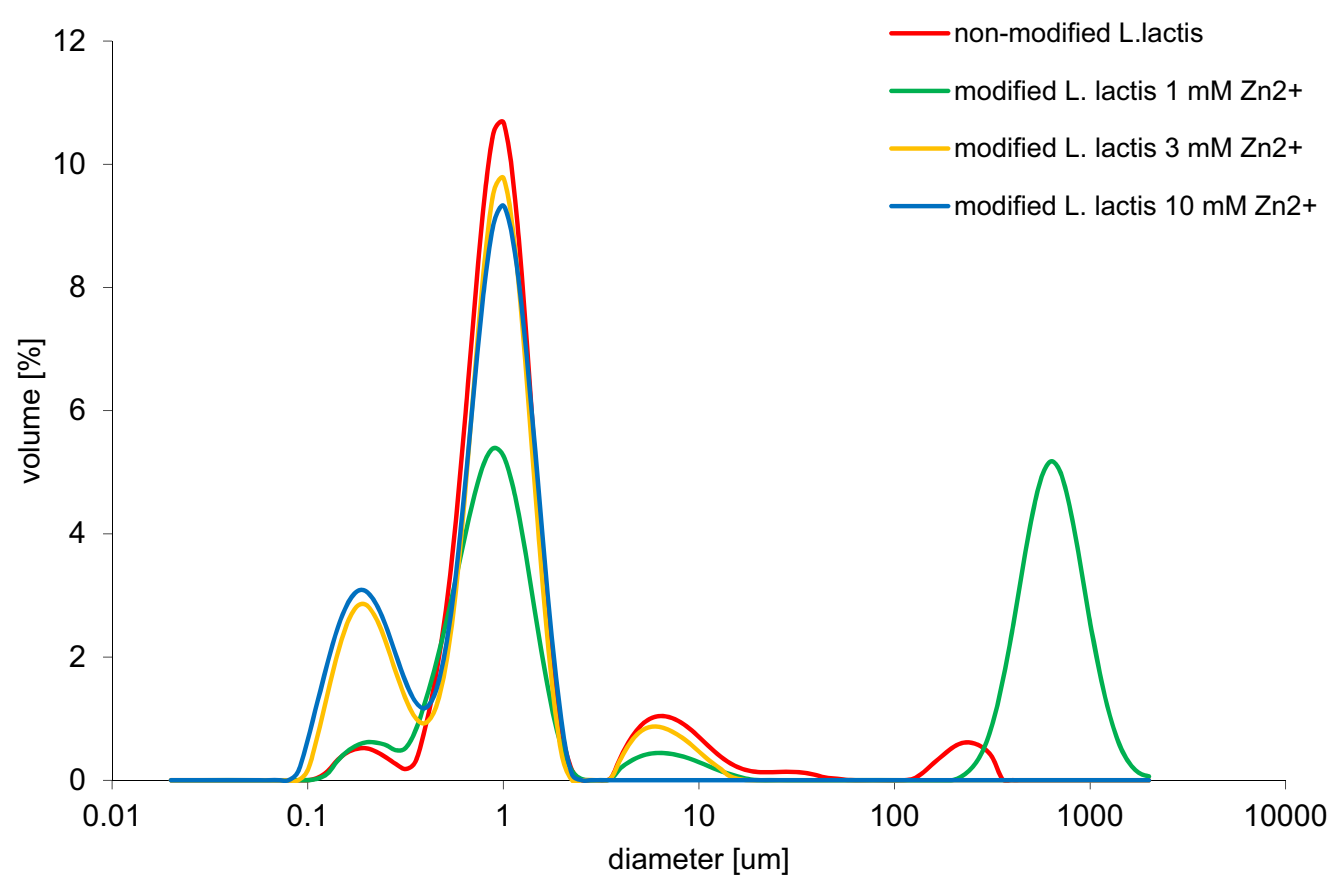

Fig. 3 Size distribution of non- and modified L. lactis cells by $\mathrm{Zn}_{\mathrm{aq}}{ }^{2+}$

Due to the promising use of capillary electrophoresis to determine cell viability, it is necessary to investigate and describe its effect on the microorganisms lifespan first. Ebersole and McCormick [41] have performed the separation of the E. faecalis, S. pyogenes, S. agalactiae, S. pneumoniae and $S$. aureus by CZE. The data from their study have indicated that more than $90 \%$ of the bacterial cells remained viable after separation. Szumski et al. [42] have executed the assessment of the viability of $S$. aureus and $E$. coli cells during capillary electrophoretic process. They have tested two different applied voltage $(20 \mathrm{kV}$ and $30 \mathrm{kV})$ and collected bacterial zones after CE were cultivated on the Broth Agar. In comparison to the control sample (without electric treatment, $0 \mathrm{kV}$ ), only $3.4 \%$ and $0.7 \%$ of the E. coli cells survived the applied voltage treatment of $20 \mathrm{kV}$ and $30 \mathrm{kV}$, respectively. $S$. aureus strains were found to be more resistant to the electric field-results of the experiment have shown that about $35 \%$ and $20 \%$ S. aureus cells survived voltage of $20 \mathrm{kV}$ and $30 \mathrm{kV}$, respectively. Szumski and coworkers [42] have emphasized such a significant differences is related to the different cell wall composition of treated strains. The bigger peptidoglycan layer of Gram $(+)(S$. aureus) cell wall make them more tough and resistant to capillary electrophoresis conditions. Data from the described papers [40, 41] are in a good correlation with those received in our studyin the fluorescence microscopy assay the amount of total cells before $\mathrm{CE}$ were compared to the control after the $\mathrm{CE}$ analysis (Fig. 5). After staining with an acridine orange and ethidium bromide, the live cells exhibit green fluorescence and dead one are visible as a red. Both of used dyes are able to intercalate or bind with the nucleic acid (DNA/RNA) present in organisms. This kind of interaction is the result of the electrostatic interactions of dyes molecules between the nucleic acid base pairs. The results of the fluorescent microscopy analysis indicated that capillary electrophoresis do not cause the death of microbial cells but only their damage (yellow colour on the Fig. 5). It can be explained by the fact if Lactococcus lactis used in our study is the Gram(+) strain with the thick peptidoglycan layer in its bacterial cell wall. Application of the fluorescence microscopy confirmed also that the modification of the bacterial cell surface with 1,3 and $10 \mathrm{mM}$ zinc ions causes their uncontrolled aggregation (Fig. 5b, c). This result is in good correlation with the data presented on the electropherograms (Fig. 1b, c, d) The results obtained during the experiment also indicate that zinc ions with the highest concentration $(10 \mathrm{mM})$ caused the higher aggregation of the Lactococcus lactis.

\section{Conclusions}

In this work, $\mathrm{CE}$ was used to evaluate the effect of zinc ions at different concentration level $(1,3$ and $10 \mathrm{mM})$ on the Lactococcus lactis cells aggregation. This study confirms 

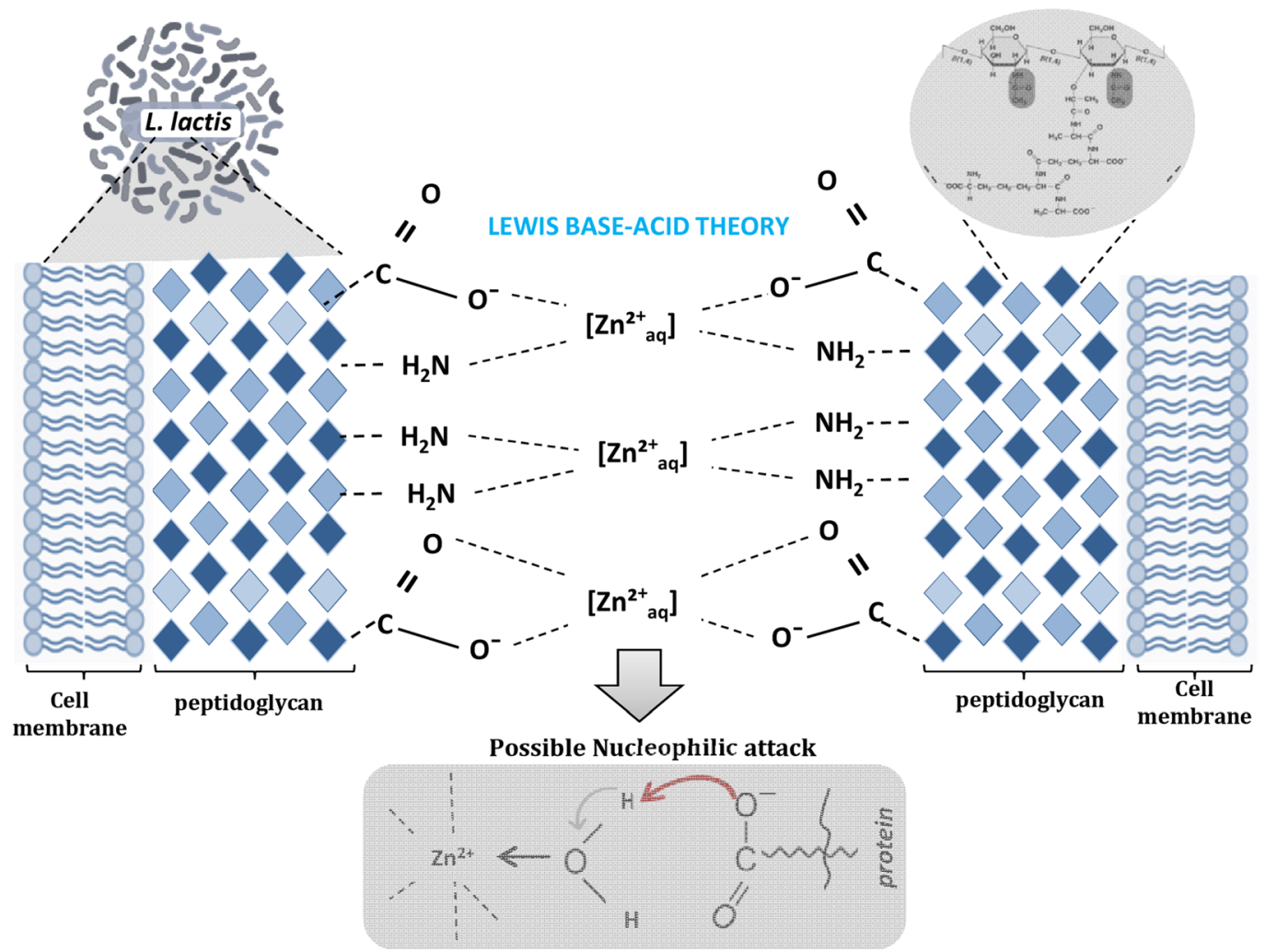

Spontaneous agglomeration

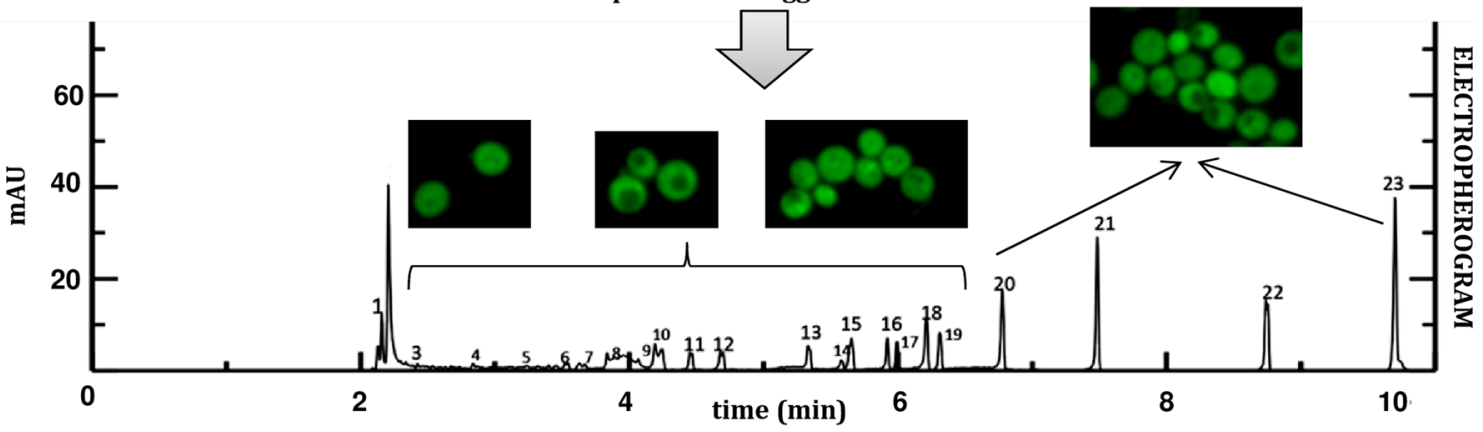

Fig. 4 The proposed mechanism of the L. lactis uncontrolled clumping

the occurrence the formation of bacterial cells agglomerates under the specific surface modification. According to the FT-IR data, the main groups involved in those process are carboxyl and amid groups which may derive from surface bacterial proteins. The results of the fluorescence microscopy showed that $L$. lactis cells stay alive after surface modification and during capillary electrophoresis. In comparison with previous work focused on the microbial surface modification by calcium ions, it can be concluded that $\mathrm{Zn}_{\mathrm{aq}}{ }^{2+}$ is not sufficient for the Lactococcus lactis controlled clumping in CE approach. However, the described work shed new light on several important issues, including an interpretation of probiotic bacteria aggregation process and understanding the influence of zinc ions on microorganisms surfaces and their potential use for further modifications, which seems to be crucial for separation science field. 


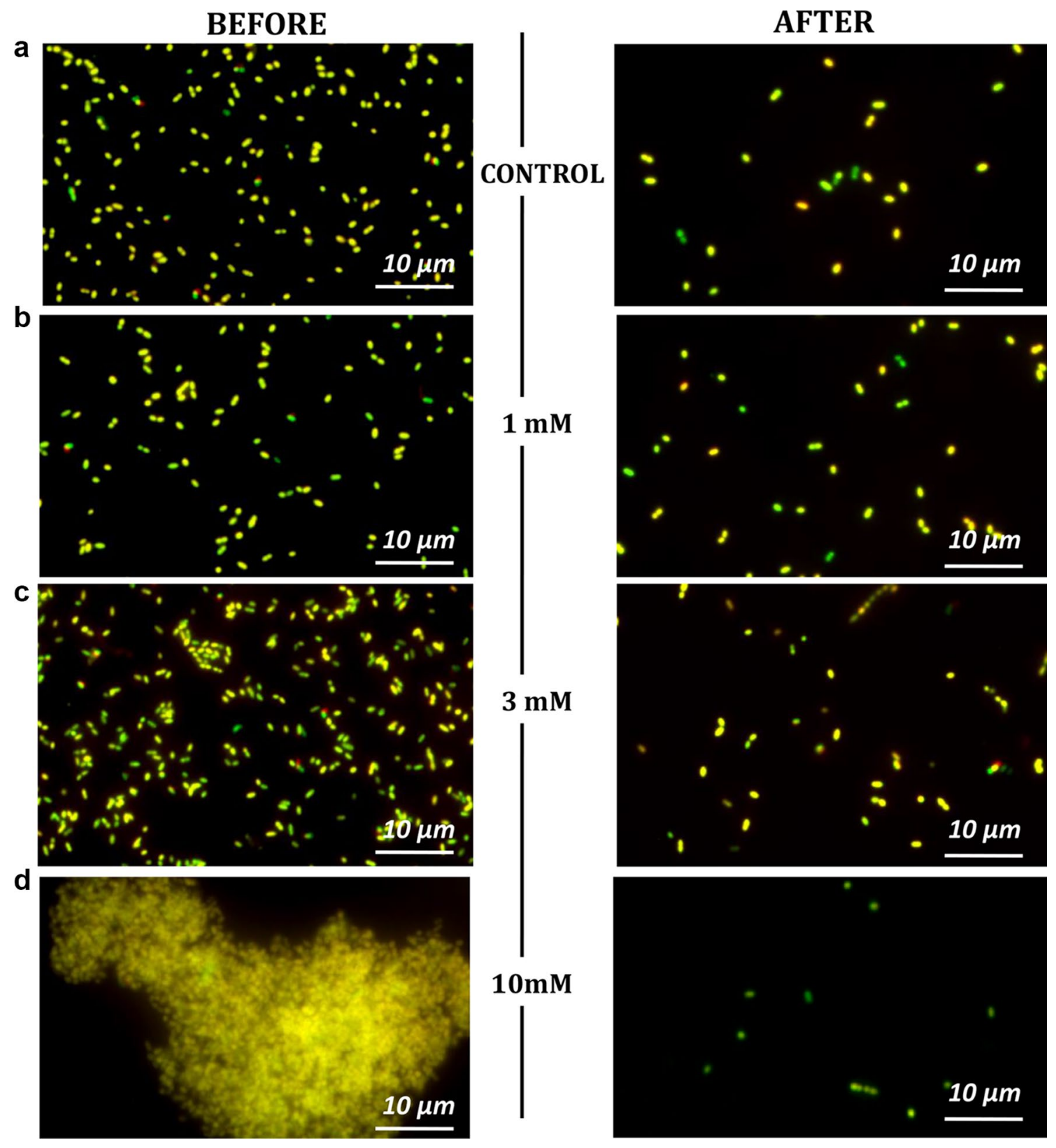

Fig. 5 Lactoccocus lactis non-modified (a) and modified by $1 \mathrm{mM}(\mathbf{b}), 3 \mathrm{mM}(\mathbf{c})$ and $10 \mathrm{mM}(\mathbf{d})$ of $\mathrm{Zn}\left(\mathrm{NO}_{3}\right)_{2}$ after the capillary electrophoresis

Acknowledgements This work was supported by the Opus 11 No. 2016/21/B/ST4/02130 (2017-2020) from the National Science Centre, Poland. Moreover, we would like to thank Dr Tomasz Kowalkowski for technical assistance in size distribution analysis.

\section{Compliance with ethical standards}

Conflict of interest The authors declared that they have not conflicts of interest.

Open Access This article is distributed under the terms of the Creative Commons Attribution 4.0 International License (http://creativeco mmons.org/licenses/by/4.0/), which permits unrestricted use, distribution, and reproduction in any medium, provided you give appropriate credit to the original author(s) and the source, provide a link to the Creative Commons license, and indicate if changes were made.

\section{References}

1. Buszewski B, Kłodzińska E (2016) Trends Anal Chem 78:95-108 
2. Klodzinska E, Kupczyk W, Jackowski M, Buszewski B (2013) Electrophoresis 34:3206-3213

3. Desai MJ, Armstrong DW (2003) Microbiol Mol Biol R 67:38

4. Szeliga J, Klodzinska E, Jackowski M, Buszewski B (2011) Med Sci Monitor 17:Mt91-Mt96

5. Schneiderheinze JM, Armstrong DW, Schulte G, Westenberg DJ (2000) Fems Microbiol Lett 189:39-44

6. Moon BG, Kim Y (2003) B Korean Chem Soc 24:1203-1206

7. Horka M, Tesarova M, Karasek P, Ruzicka F, Hola V, Sittova M, Roth M (2015) Anal Chim Acta 868:67-72

8. Shen Y, Berger SJ, Smith RD (2000) Anal Chem 72:4603-4607

9. Okun VM, Moser R, Blaas D, Kenndler E (2001) Anal Chem 73:3900-3906

10. Grossman PD, Soane DS (1990) Anal Chem 62:1592-1596

11. Dziubakiewicz E, Buszewski B (2014) Electrophoresis 35:1160-1164

12. Dufrene YF, Boonaert CJP, van der Mei HC, Busscher HJ, Rouxhet PG (2001) Ultramicroscopy 86:113-120

13. Salton MRJ (1953) Biochim Biophys Acta 10:512-523

14. Vollmer W, Blanot D, De Pedro MA (2008) FEMS Microbiol Rev 32:149-167

15. Armstrong DW, Schulte G, Scneiderheinze JM, Westenberg DJ (1999) Anal Chem 71:5465

16. Scneiderheinze JM, Armstrong DW, Schulte G, Westenberg DJ (2000) FEMS Microbiol Lett 189:39

17. Klodzinska E, Dahm H, Rozycki H, Szeliga J, Jackowski M, Buszewski B (2006) J Sep Sci 29:1180

18. Buszewski B, Szumski M, Kłodzińska E, Dahm H (2003) J Sep Sci 26:1045-1049

19. Buszewski B, Kłodzińska E (2008) Electrophoresis 29:4177-4184

20. Yu LJ, Li SFY (2005) Chromatographia 62:401

21. Rogowska A, Pomastowski P, Złoch M, Railean-Plugaru V, Król A, Rafińska K, Szultka-Młyńska M, Buszewski B (2018) Nat-Sci Rep 8:7261

22. Railean-Plugaru V, Pomastowski P, Meller K, Złoch M, Rafińska K, Buszewski B (2017) Appl Microbiol Biotechnol 101:7141-7153
23. Pomastowski P, Szultka-Młyńska M, Kupczyk W, Jackowski M, Buszewski B (2015) J Anal Bioanal Tech S13:1-7

24. Hermansson M (1999) Coll Surf B 14:105-119

25. Klug A, Rhodes D (1987) Cold Spring Harb Symp Quant Biol $52: 473-482$

26. Schwarzenbach G (1956) Experientia 5:162-192

27. Ahrland S, Chatt J, Davies NR (1958) Chem Soc Rev 12:265-276

28. Krężel A, Maret W (2016) Arch Biochem Biophys 611:3-19

29. Kochańczyk T, Drozd A, Krężel A (2015) Metallomics 7:244-257

30. Bielański A (1997) Podstawy Chemii Nieorganicznej. PWN, Warszawa

31. Flemming HC, Wingender J, Griebe T, Mayer C (2000) In: Evans LV (ed) Biofilms: recent advances in their study and control. CRC Press, Boca Raton

32. Salter MH, Reibenspies JH, Jones SB, Hancock RD (2005) Inorg Chem 44:2791-2797

33. Salas-Jara MJ, Ilabaca A, Vega M, García A (2016) Microorganisms $4: 35$

34. Formosa-Dague C, Speziale P, Foster TJ, Geoghegan JA, Dufrêne YF (2016) Proc Natl Acad Sci 113:410-415

35. Brown LR, Caulkins RC, Schartel TE, Rosch JW, Honsa ES, Schultz-Cherry S, Thornton JA (2017) Front Cell Infect Microbiol $7: 233$

36. Salminen S, Von Wright A (2011) Lactic acid bacteria: microbiological and functional aspects. CRC Press, London

37. Król A, Railean-Plugaru V, Pomastowski P, Złoch M, Buszewski B (2018) Coll Surf A. https://doi.org/10.1016/j.colsu rfa.2018.05.069

38. Naumann D, Keller S, Helm D, Schultz C, Schrader B (1995) J Mol Struct 347:399-405

39. Pomastowski P, Sprynskyy M, Buszewski B (2014) Coll Surf B 120:21-27

40. Ru QH, Luo GA, Liao JJ, Liu Y (2000) J Chrom A 894:165-170

41. Ebersole RC, McCormick RM (1993) Nat Biotechnol 11:1278

42. Szumski M, Kłodzińska E, Dziubakiewicz E, Hrynkiewicz K, Buszewski B (2011) J Liq Chromatogr Relat Technol 34:2689-2698 